\title{
Irfani
}

ISSN 1907-0969 E ISSN 2442-8272

Volume 16 Nomor 1 Juni 2020

Halaman 82-95

http://journal.iaingorontalo.ac.id/index.php/ir

\section{INTEGRASI NILAI-NILAI PENDIDIKAN KARAKTER PADA MATA PELAJARAN PAI DAN BUDI PEKERTI (STUDI PUSTAKA PADA BUKU PAI DAN BP UNTUK SMK KELAS X)}

\author{
Kusmawaty Matara \\ IAIN Sultan Amai Gorontalo \\ email: kusmawaty.matara83@gmail.com
}

\begin{abstract}
ABSTRAK
Penelitian ini bertujuan untuk mengetahui muatan nilai-nilai pendidikan karakter pada buku pelajaran PAI dan Budi pekerti kelas X SMK dan strategi pengintegrasian nilai-nilai pendidikan karakter pada buku PAI dan budi pekerti kelas X SMK. Penelitian ini termasuk penelitian kualitatif, dengan menggunakan metode content analisis (analisis isi).Sumber data dalam penelitian ini yaitu buku ajar Buku Pendidikan Agama Islam dan Budi Pekerti kelas X Sekolah Menengah Kejuruan (SMK) diterbitkan oleh penerbit Erlangga.Tim penyusunnya yaitu Drs. $H$. Abd.Rahman, MA, Dra.Hj.Lim Halimah, Munawir A.M., Drs. HA. Sholeh Dimyathi, MF, MM., Drs. H. Ridwan, Ms, MM. Nilai-nilai pendidikan karakter yang terkandung atau termuat didalam buku ajar Pendidikan Agama Islam dan Budi Pekerti SMK kelas X yang ditemukan peneliti yaitu Religius, kerja keras, semangat kebangsaan, bersahabat/komunikatif, cinta damai, peduli lingkungan, peduli social, tanggung jawab, demokrasi, disiplin, jujur, rasa ingin tahu, menghargai prestasi, gemar membaca, kreatif, toleransi. Didalam buku mata pelajaran ini juga terdapat intruksi atau petunjuk-petunjuk yang tidak jauh berbeda dengan strategi yang digunakan untuk menyampaikan materi. Buku teks ini baik digunakan dalam proses pembelajaran karena materi yang terdapat didalam buku sudah termuat nilai-nilai karakter, hanya perlu disempurnakan pada proses pembelajaran atau kegiatan pembelajaran.
\end{abstract}

Kata Kunci : Nilai-nilai Pendidikan Karakter, Buku Teks PAI

\section{ABSTRACT}

This study aims to determine the content of the values of character education in the PAI textbooks and the $\mathrm{X}$ class of Vocational High School Characteristics and the strategy of integrating the values of character education in the PAI book and character education for class $\mathrm{X}$ SMK. This research is a qualitative research, using content analysis method (content analysis). The source of data in this study is the textbook of Islamic Education and Character Class X Vocational Schools (SMK) published by Erlangga publisher. The compilation team is Drs. H. Abd.Rahman, MA, Dra.Hj.Lim Halimah, Munawir A.M., Drs. HA. Sholeh Dimyathi, MF, MM., Drs. H. Ridwan, Ms, MM.The values of character education contained or contained in the 


\section{Irfani}

ISSN 1907-0969 E ISSN 2442-8272

Volume 16 Nomor 1 Juni 2020

Halaman 82-95

http://journal.iaingorontalo.ac.id/index.php/ir

textbooks of Islamic Education and Vocational School Class X Characteristics found by researchers are religious, hard work, national spirit, friendly / communicative, peace-loving, environmental care, social care, responsibility, democracy. , discipline, honesty, curiosity, respect for achievement, fond of reading, creative, tolerance. In this subject book there are also instructions or pointers that are not much different from the strategies used to convey the material.This textbook is good for use in the learning process because the material contained in the book contains character values, it only needs to be refined in the learning process or learning activities.

Keywords: Character Education Values, PAI Textbook

\section{PENDAHULUAN}

Pendidikan karakter menjadi isu utama dalam pendidikan. Selain menjadi bagian dari proses pembentukkan akhlak anak bangsa, pendidikan karakter diharapkan mampu menjadi pondasi utama dalam meningkatkan derajat dan martabat bangsa Indonesia. Individu yang memiliki karakter yang baik merupakan usaha seseorang untuk melakukan hal-hal yang baik kepada Allah SWT. Sesama manusia dan alam sekitarnya. berusaha melakukan hal terbaik sesuai dengan kompetensi dan potensi yang dimilikinya.

Pembangunan karakter bangsa dijadikan sebagai arus utama pembangunan nasional. Bahwa setiap upaya pembangunan karakter selalu diarahkan untuk dapat memberikan dampak positif terhadap pengembangan karakter. Menurut Confusius, seorang filosof Cina, manusia pada dasarnya memiliki potensi mencintai kebajikan. Namun apabila potensi ini tidak diikuti dengan pendidikan dan sosialisasi setelah manusia dilahirkan, maka manusia dapat berubah menjadi binatang, bahkan lebih buruk lagi. Oleh karena itu, sosialisasi dan pendidikan anak yang berkaitan dengan nilai-nilai kebajikan baik di keluarga maupun di sekolah dan lingkungan yang lebih luas, sangat penting dalam pembentukan karakter anak ${ }^{1}$. Salah satu lembaga yang mempunyai peranan yang sangat penting dalam mengembangkan dan menanamkan karakter mulia adalah pendidikan. Pendidikan merupakan salah satu upaya untuk membentuk watak dan kepribadian seseorang seperti yang tertuang di dalam Undang-Undang Republik Indonesia Nomor 20 tahun 2003 tentang Sistem Pendidikan Nasional. Dalam Undang-Undang Sistem Pendidikan Nasional, karakter penting yang semestinya dibangun adalah peserta didik yang menjadi manusia yang beriman dan bertakwa kepada Tuhan Yang Maha Esa. ${ }^{2}$

Penguatan pendidikan karakter disekolah dapat dilaksanakan dengan memaksimalkan Mata pelajaran Pendidikan Agama Islam yang tidak hanya menekankan pada aspek kognitif sebagai transformasi pengetahuan pada segi keagamaan, tetapi pada aspek afektif sebagai

\footnotetext{
${ }^{1}$ Sari, Dewi Purnama. 2017. "Pendidikan Karakter Berbasis Al-Quran”. Islamic Counseling, 1 (1): 1-24. PISSN 2580-3638, E-ISSN 2580-3646.

${ }^{2}$ Undang-undang Nomor 20 Tahun 2003 pasal 3 tentang Sistem Pendidikan
} 


\section{Irfani}

ISSN 1907-0969 E ISSN 2442-8272

Volume 16 Nomor 1 Juni 2020

Halaman 82-95

http://journal.iaingorontalo.ac.id/index.php/ir

transformasi norma dan nilai moral dalam membentuk sikap dan pada aspek psikomotoriknya yang berperan dalam mengendalikan perilaku sebagai upaya tercipta manusia seutuhnya. Pada mata pelajaran PAI didasarkan kepada dua sumber pokok ajaran Islam yaitu Al-Quran dan AsSunnah/Hadist Nabi Muhammad saw.

Mengintegrasikan nilai-nilai karakter pada mata pelajaran Pendidikan Agama Islam merupakan tugas dan tanggung jawab guru yang sangat besar. .Pola integrasi karakter dalam proses pembelajaran Pendidikan Agama Islam meliputi integrasi pada Rencana Pelaksanaan Pembelajaran Pendidikan Agama Islam, yaitu bagaimana cara guru mencantumkan kompetensi karakter pada kompetensi dasar, merumuskan nilai-nilai karakter pada tujuan dan indikator pembelajaran ${ }^{3}$. Guru Pendidikan Agama Islam juga harus melatih keterampilannya mengembangkan materi yang berkarakter, strategi dan metode pembelajaran yang dapat menumbuhkan kembangkan nilai-nilai karakter peserta didik. Selain itu guru juga harus merumuskan media dan sumber belajar yang bervariasi. Hal ini karena lingkungan pergaulan peserta didik yang sangat rentan dengan tindakan yang kurang baik. Maka perlu usaha kreatif guru Pendidikan Agama Islam dalam mengintegrasikan nilai-nilai karakter tersebut.

Muatan pendidikan karakter diharapkan agar dapat membenahi karakter dan mental peserta didik agar tetap sesuai dengan tantangan dan tuntutan zaman. Salah satu komponen penting yaitu materi ajar Pendidikan Agama Islam dan Budi Pekerti yang didalamnya terdapat materi-materi tentang akhlak yang tidak berbeda dengan karakter maka isi materi haruslah tersusun muatan-muatan pendidikan karakter agar peserta didik mampu memahami arti dan mengamalkannya.

Berdasarkan latar belakang di atas, maka penulis membuat rumusan masalah dalam artikel ini sebagai berikut:

1. Apa saja muatan Pendidikan Karakter dalam Buku siswa PAI dan Budi Pekerti untuk SMK Kelas X?

2. Bagaimana Strategi Pengintegrasian nilai-nilai pendidikan Karakter dalam Buku SiswaPAI dan Budi Pekerti untuk SMK Kelas X?

\section{LANDASAN TEORI}

\section{Pengertian karakter}

Karakter secara kebahasaan ialah sifat-sifat kejiwaan, akhlak atau budi pekerti yang membedakan seseorang dari yang lain, tabiat, atau watak. Kata karakter dipungut dari Bahasa Inggris character yang artinya watak, sifat, peran, huruf, sedangkan characteristic artinya sifat yang khas. Karakter telah menjadi bahasa Indonesia, yang semula dari Bahasa Inggris (character) dan lebih jauh lagi dari Bahasa Yunani charassein yang artinya "mengukir corak

${ }^{3}$ Risnawati, Implementasi Niai-Nilai Karakter pada Mata Pelajaran Pendidikan Agama Islam (PAI) Tingkat SLTA, (Pontianak: IAIN Pontianak Press, 2014), hal. 19. 


\section{Irfani}

ISSN 1907-0969 E ISSN 2442-8272

Volume 16 Nomor 1 Juni 2020

Halaman 82-95

http://journal.iaingorontalo.ac.id/index.php/ir

yang tetap dan tidak terhapuskan" sehingga dalam makna terminology, karakter atau watak "merupakan perpaduan dari segala tabiat manusia yang bersifat tetap sehingga menjadi tanda khusus untuk membedakan orang yang satu dengan yang lain ${ }^{4}$.

Kata karakter berasal dari Bahasa Yunani yang berarti "to mark" (menandai) dan memfokuskan pada bagaimana mengaplikasikan nilai kebaikan dalam bentuk tindakan atau tingkah laku ${ }^{5}$. Selain itu diartikan sebagai gambaran tingkah laku yang menonjolkan nilai benarsalah, baik-buruk, baik secara eksplisit maupun implisit ${ }^{6}$. Sedangkan dalam Undang-Undang Nomor 20 Tahun 2013 pasal 3 tentang Sistem Pendidikan berbunyi, Pendidikan nasional berfungsi mengembangkan kemampuan dan membentuk karakter serta peradaban bangsa yang bermartabat dalam rangka mencerdaskan kehidupan bangsa. Bertujuan mengembangkan potensi peserta didik agar menjadi manusia yang beriman dan bertakwa kepada Tuhan Yang Maha Esa, berakhlak mulia, sehat, berilmu, cakap, kreatif, mandiri dan menjadi warga negara yang demokratis serta bertanggung jawab.

Berdasarkan pengertian diatas karakter yaitu, perpaduan dari segala tabiat manusia yang bersifat tetap sehingga menjadi tanda khusus untuk membedakan orang yang satu dengan yang lain. Karakter merupakan tabiat atau kepribadian yang baik, akhlak mulia yang didasarkan pemahaman dan penghayatan tentang kebaikan, serta berkomitmen melaksanakan kebaikan itu, dengan memberi manfaat besar terhadap sekililingnya.

\section{Deskripsi Nilai Pendidikan Karakter.}

Pendidikan karakter dilakukan melalui Pendidikan nilai-nilai atau kebajikan yang menjadi nilai dasar karakter bangsa. Kebajikan yang menjadi atribut suatu karakter pada dasarnya adalah nilai.Oleh karena itu, Pendidikan karakter pada dasarnya adalah pengembangan nilai-nilai yang berasal dari pandangan hidup atau ideologi bangsa Indonesia, agama, budaya, dan nilai-nilai yang terumuskan dalam tujuan Pendidikan nasional.

Nilai-nilai yang dikembangkan dalam Pendidikan karakter di Indonesia di identifikasi berasal dari 4 sumber,). Pertama, agama. masyarakat Indonesia merupakan masyarakat beragama.Kehidupan individu, masyarakat, dan bangsa selalu didasari pada ajaran agama dan kepercayaannya. Secara politis, kehidupan kenegaraan pun didasari pada nilai-nilai yang berasal dari agama. Karenanya, nilai-nilai Pendidikan karakter harus didasarkan pada nilai-nilai dan kaidah yang berasal dari agama.

\footnotetext{
${ }^{4}$ Nasir, Haedar, 2013. Pendidikan Karakter Berbasis Agama dan Budaya. Yogyakarta: Multi Pressindo.

${ }^{5}$ Wynne, E. A. 1991. "Character And Academics In The Elementary School”. Dalam Benninga J.S. (Penyunting). Moral, Character,And Civic Education In The ElementarySchool. New York: Teachers College, Columbia University.

${ }^{6}$ Alwisol. 2006. Psikologi Kepribadian. Malang : UMM.
} 


\section{Irfani}

ISSN 1907-0969 E ISSN 2442-8272

Volume 16 Nomor 1 Juni 2020

Halaman 82-95

http://journal.iaingorontalo.ac.id/index.php/ir

Kedua, Pancasila. Negara Kesatuan Republik Indonesia ditegakkan atas prinsip-prinsip kehidupan kebangsaan dan kenegaraan yang disebut Pancasila.Pancasila terdapat pada pembukaan UUD 1945 yang dijabarkan lebih lanjut ke dalam pasal-pasal yang terdapat dalam UUD 1945. Artinya, nilai-nilai yang terkandung dalam Pancasila menjadi nilai-nilai yang mengatur kehidupan politik, hukum, ekonomi, kemasyarakatan, budayadan seni.Pendidikan budaya dan karakter bangsa bertujuan mempersiapkan peserta didik menjadi warga negara yang lebih baik, yaitu warga negara yang memiliki kemampuan, kemauan, dan menerapkan nilai-nilai pancasila dalam kehidupannya sebagai warga negara.

Ketiga, budaya.Sebagai suatu kebenaran bahwa tidak ada manusia yang hidup bermasyarakat yang tidak didasari nilai-nilai budaya yang diakui masyarakat tersebut.Nilai budaya ini di jadikan dasar dalam pemberian makna terhadap suatu konsep dan arti dalam komunikasi antaranggota masyarakat tertentu.Posisi budaya yang sedemikian penting dalam kehidupan masyarakat mengharuskan budaya menjadi sumber nilai dalam Pendidikan budaya dan karakter bangsa.

Keempat, tujuan Pendidikan Nasional. UU RI Nomor 20 tahun 2003 tentang Sistem Pendidikan Nasional merumuskan fungsi dan tujuan Pendidikan nasional yang harus digunakan dalam mengembangkan upaya Pendidikan di Indonesia. Pasal 3 UU Sisdiknas menyebutkan "Pendidikan nasional berfungsi mengembangkan dan membentuk watak serta peradaban bangsa yang bermartabat dalam rangka mencerdaskan kehidupan bangsa, bertujuan untuk berkembangnya potensi peserta didik agar menjadi manusia yang beriman dan bertakwa kepada Tuhan Yang Maha esa, berakhlak mulia, sehat, berilmu, cakap, kreatif, mandiri, dan menjadi negara yang demokratis dan bertanggung jawab." Pendidikan nasional sebagai rumusan kualitas yang harus dimiliki oleh setiap warga negara Indonesia, dikembangkan oleh berbagai satuan Pendidikan di berbagai jenjang dan jalur.Tujuan Pendidikan nasional memuat berbagai nilai kemanusiaan yang harus dimiliki warga negara Indonesia. ${ }^{8}$ Oleh karena itu, tujuan Pendidikan nasional adalah sumber yang paling operasional dalam pengembangan Pendidikan dan budaya karakter bangsa.

\section{Buku Ajar Pendidikan Agama Islam \& Budi Pekerti}

Sanjaya Pendidikan Agama Islam \& Budi Pekerti merupakan seperangkat materi yang disusun secara sistematis sehingga tercipta lingkungan atau suasana yang memungkinkan peserta didik belajar dengan baik. ${ }^{9}$ Buku teks PAI adalah buku yang berisi uraian materi Pendidikan Agama Islam memberikan pengetahuan serta membentuk sikap, kepribadian dan keterampilan peserta didik dalam mengamalkan ajaran agama, dan disusun secara sistematis berdasarkan

\footnotetext{
${ }^{7}$ Putri Puspitaningsih, Sumber-sumber Pendidikan Karakter, (STKIP PGRI Pacitan), 2013/2014.

8 Zubaedi, 2011.Desain Pendidikan Karakter: Konsepsi dan Aplikasinya dalam Lembaga Pendidikan. Jakarta: Kencana.

${ }^{9}$ Sanjaya, Wina, 2010, Perencanaan dan Sistem Desain Pembelajaran, Jakarta: Kencana.
} 


\section{Irfani}

ISSN 1907-0969 E ISSN 2442-8272

Volume 16 Nomor 1 Juni 2020

Halaman 82-95

http://journal.iaingorontalo.ac.id/index.php/ir

kurikulum tertentu, telah melalui seleksi berdasarkan tujuan pembelajaran, orientasi serta mengacu pada perkembangan peserta didik.

\section{METODOLOGI PENELITIAN}

Penelitian ini termasuk penelitian kualitatif, penelitian kualitatif merupakan penelitian deskriptif karena penelitian ini berusaha mengambarkan data dengan kalimat yang dipisahkan menurut kategori untuk memperoleh kesimpulan dari. ${ }^{10}$ Jenis penelitian ini adalah mencari, menganalisis, membuat interpretasi dan melakukan generalisasi pada penelitian yang dilakukan.Sehingga menghasilkan data deskriptif yaitu data tertulis setelah menganalisis pemikiran dari suatu teks bacaan maupun sumber tertulis buku teks mata pelajaran PAI dan Budi Pekerti kelas X SMK untuk mengetahui muatan-muatan nilai pendidikan karakter dan strategi pengintegrasian nilai-nilai pendidikan karakter di dalam buku teks mata pelajaran.

Metode yang digunakan untuk mendapatkan data-data penelitian, penulis mengumpulkan bahan-bahan kepustakaan yang berkaitan dengan konsep karakter dan integrasi nilai-nilai pendidikan karakter pada mata pelajaran PAI. Kemudian data yang disajikan berbentuk kata atau kalimat dan memerlukan pengolahan agar ringkas dan sistematis.Sumber data dalam penelitian ini adalah buku ajar Buku Pendidikan Agama Islam dan Budi Pekerti kelas X Sekolah Menengah Kejuruan (SMK) diterbitkan oleh penerbit Erlangga. Kurikulum 2013 edisi Revisi 2016 dan terdiri dari 235 halaman. Dalam Analisis data dalam penelitian kepustakaan ini menggunakan analisis isi atau Content analysis, menjelaskan penelitian yang bersifat pembahasan mendalam terhadap isi suatu informasi tertulis ataupun tercetak dalam buku atau media masa. Tahapannya adalah menentukkan permasalahan, menyusun kerangka berpikir, analisis isi dan menginterpretasikan data-data tersebut.

\section{HASIL PENELITIAN}

Buku Pendidikan Agama Islam dan Budi Pekerti kelas X Sekolah Menengah Kejuruan (SMK) diterbitkan oleh penerbit Erlangga. Tim penyusunnya yaitu Drs. H. Abd.Rahman, MA, Dra.Hj.Lim Halimah, Munawir A.M., Drs. HA. Sholeh Dimyathi, MF, MM., Drs. H. Ridwan, Ms, MM. Buku ini merupakan bagian integral dari pembelajaran PAI Model DSL (Dakwah Sistem Langsung, merupakan sebuah model yang menurut Prof. Dede Rosyada, paling fenomenal) yang dikembangkan di SMK. Kemudian buku ini juga berbasis Al-Quran dan tidak mengesampingkan rujukan dari hadits dan ijtihad para ulama. ${ }^{11}$

\footnotetext{
${ }^{10}$ Arikunto, S 2010. Prosedur Penelitian Suatu pendekatan Praktik. Jakarta; Rineka Cipta.

${ }^{11}$ Agama Islam dan Budi Pekerti untuk SMK Kelas X Kurikulum 2013,Edisi Revisi 2016, Jakarta: Penerbit Erlangga, 2016.
} 


\section{Irfani}

ISSN 1907-0969 E ISSN 2442-8272

Volume 16 Nomor 1 Juni 2020

Halaman 82-95

http://journal.iaingorontalo.ac.id/index.php/ir

Dalam buku ajar Pendidikan Agama Islam dan Budi pekerti kelas X SMK terdapat 15 Bab, yaitu:

1. Kajian Q.S. Al-Anfal [8]: 72 dan Hadist tentang pentingnya mengendalikan diri (Mujahadah an Nafs)

2. Kajian Q.S Al-Hujurat [49]: 12 dan Hadist tentang Berprasangka Baik (Huznuzzan)

3. Kajian Q.S Al-Hujurat [49]: 10 dan Hadist tentang indahnya persaudaraan (Ukhuwah)

4. Kajian Q.S Al-isra [17]: 32, Q.S An-Nur [24]:2 dan hadist tentang menjaga diri dari pergaulan bebas dan Zina

5. Meneladani Allah SWT. Melalui Asmaul Husna

6. Menghadirkan malaikat dalm kehidupan sehari-hari

7. Meningkatkan martabat diri dengan Berpakaian Syar'i

8. Jujur membawa hidup penuh berkah

9. Gemar menuntut ilmu dan mengamalkannya

10. Membiasakan hidup berlandaskan hukum Islam

11. Menyempurnakan agama melalui haji dan umroh

12. Menumbuhkan solidaritas sosial melalui zakat

13. Meningkatkan kesejateraan umat melalui waqaf

14. Meneladani dakwah Rasulullah saw. periode Makkah

15. Meneladani dakwah Rasullulah saw. periode Madinah

Muatan-muatan nilai-nilai pendidikan karakter dan budi Pekerti pada buku siswa mata pelajaran PAI kelas X SMK

Nilai-nilai pendidikan karakter yang dikembangkan oleh Kementerian Pendidikan ada 18 karakter.nilai-nilai tersebut bersumber dari agama, pancasila, budaya, dan tujuan pendidikan nasional. Adapun 18 nilai tersebut yaitu : religious, jujur, toleransi, disiplin, kerja keras, kreatif, mandiri, demokratis, rasa ingin tahu, semangat kebangsaan, cinta tanah air, menghargai prestasi, bersahabat/komunikatif, cinta damai, gemar membaca, peduli lingkungan, peduli sosial dan tanggung jawab.

Nilai-nilai karakter yang terkandung pada materi ini yaitu : Religius, cinta damai, toleransi, peduli lingkungan, peduli sosial, semangat kebangsaan, kerja keras, bersahabat/komunikatif, tanggung jawab

Dalam Buku Erlangga (2016). Toleransi dan demokratis ditunjukkan pada sikap dan perilaku yang mencerminkan ayat yaitu, persaudaraan yang terjalin antar sesama muslim bermakna ganda: pertama, didasari iman atau aqidah dan kedua, persaudaraan satu keturunan meski bukan dalam makna hakiki. Melalui pemahaman ini antar sesama muslim harus menyatu lahir dan batin, senasib sependeritaan, sedih dan gembira sama-sama dirasakan Terus 


\section{Irfani}

ISSN 1907-0969 E ISSN 2442-8272

Volume 16 Nomor 1 Juni 2020

Halaman 82-95

http://journal.iaingorontalo.ac.id/index.php/ir

menumbuhkan persaudaraan internal untuk umat islam yang sejati antara umat islam dengan komunitas agama lain, dan antar sesama makhluk ciptaan Allah.

Sikap peduli sosial ditunjukkan pada cerita saat seorang sahabat Rasul kehausan, ia malah memberikan jatah airnya kepada sahabat yang lainnya yang merintih kehausan juga. Namun setelah diberi, air itu malah diberikan kembali ke sahabat yang lain. Terus begitu hingga semua mati syahid dalam kondisi kehausan.Mereka mengutamakan saudaranya sendiri dibandingkan dirinya.Inilah ciri utama dari ukhuwwah Islamiyah. Rasulullah saw. pernah bersabda: "Tidak beriman seseorang di antara kamu hingga kamu mencintai saudaramu seperti kamu mencintai dirimu sendiri.” (H.R. Bukhari dan Muslim) dalam Buku Erlangga (2016).

sikap religious, disiplin dan tanggung jawab ditunjukkan pada larangan mendekati sesuatu yang mengundang nafsu, larangan agar tidak terjerumus rayuan yang berpotensi untuk melakukannya. Bukan hanya kaum perempuan akan tetapi kepada kaum laki-laki juga bahwa pentingnya menjaga pergaulannya agar perbuatan zina tidak terjadi. Hal ini berlaku untuk semua kaum muslimin. Harus memiliki keyakinan bahwa pola hidup yang sejalan dengan aturan Allah SWT., menuntun pada kesuksesan sejati dan kebahagiaan hakiki. Setiap muslim harusmerenungkan secara mendalam tentang aturan-aturan Allah SWT, tentang tata pergaulan lawan jenis. Nilai-nilai karakter yang terkandung pada materi ini yaitu: religious, tanggung jawab dan disiplin.

a. Meneladani Allah SWT. Melalui Asmaul Husna

b. Menghadirkan Malaikat dalam Kehidupan Sehari-hari

c. Meningkatkan Martabat Diri dengan Berpakaian Syar'i

d. Jujur Membawa Hidup Penuh Berkah

e. Gemar Menuntut Ilmu dan Mengamalkannya.

f. Membiasakan Hidup Berlandaskan Hukum Islam

g. Menyempurnakan Agama Melalui Haji dan Umrah

h. Menumbuhkan Solidaritas Sosial Melalui Zakat

i. Meningkatkan kesejahterahkan Umat Melalui Wakaf

j. Meladani Dakwah Rasulullah SAW Periode Mekkah

k. Meneladani Dakwah Rasulullah SAW Periode Madinnah 


\section{Irfani}

ISSN 1907-0969 E ISSN 2442-8272

Volume 16 Nomor 1 Juni 2020

Halaman 82-95

http://journal.iaingorontalo.ac.id/index.php/ir

Tabel. 1 Muatan nilai-nilai pendidikan Karakter pada buku Mata Pelajaran Pendidikan Agama Islam dan Budi Pekerti SMK kelas X

\begin{tabular}{|l|l|l|}
\hline No. & \multicolumn{1}{|c|}{ Aspek/Materi } & Nilai-nilai pendidikan Karakter \\
\hline 1. & $\begin{array}{l}\text { Kajian Q.S. Al-Anfal [8]: 72 dan } \\
\text { Hadist tentang pentingnya } \\
\text { mengendalikan diri (Mujahadah } \\
\text { an Nafs) }\end{array}$ & $\begin{array}{l}\text { Religius, kerja keras, semangat } \\
\text { kebangsaan, } \\
\text { bersahabat/komunikatif, cinta } \\
\text { damai, peduli lingkungan, peduli } \\
\text { sosial, tanggung jawab }\end{array}$ \\
\hline 2. & $\begin{array}{l}\text { Kajian Q.S Al-Hujurat [49]: 12 } \\
\text { dan Hadist tentang Berprasangka } \\
\text { Baik (Huznuzzan) }\end{array}$ & $\begin{array}{l}\text { Religious, peduli lingkungan, } \\
\text { peduli sosial, cinta damai, jujur, } \\
\text { tanggung jawab, bersahabat } \\
\text { komunikatif }\end{array}$ \\
\hline 3. & $\begin{array}{l}\text { Kajian Q.S Al-Hujurat [49]: 10 } \\
\text { dan Hadist tentang indahnya } \\
\text { persaudaraan (Ukhuwah) }\end{array}$ & $\begin{array}{l}\text { Religious, cinta damai, toleransi, } \\
\text { peduli sosial, semangat } \\
\text { kebangsaan, demokratis. }\end{array}$ \\
\hline 4. & $\begin{array}{l}\text { Kajian Q.S Al-isra [17]: 32, Q.S } \\
\text { An-Nur [24]:2 dan hadist tentang } \\
\text { menjaga diri dari pergaulan bebas } \\
\text { dan Zina }\end{array}$ & $\begin{array}{l}\text { Religious, disiplin, tanggung } \\
\text { jawab }\end{array}$ \\
\hline 5. & $\begin{array}{l}\text { Meneladani Allah SWT. Melalui } \\
\text { Asmaul Husna }\end{array}$ & $\begin{array}{l}\text { Religious, tanggung jawab, kerja } \\
\text { keras, peduli social, cinta damai }\end{array}$ \\
\hline 6. & $\begin{array}{l}\text { Menghadirkan Malaikat dalam } \\
\text { Kehidupan Sehari-hari }\end{array}$ & $\begin{array}{l}\text { Religious, disiplin, jujur, } \\
\text { tanggung jawab, }\end{array}$ \\
\hline 7. & $\begin{array}{l}\text { Meningkatkan Martabat Diri } \\
\text { dengan Berpakaian Syar'i }\end{array}$ & $\begin{array}{l}\text { Religious, disiplin, tanggung } \\
\text { jawab }\end{array}$ \\
\hline 8. & $\begin{array}{l}\text { Jujur Membawa Hidup Penuh } \\
\text { Berkah }\end{array}$ & $\begin{array}{l}\text { Religious, jujur, disiplin, } \\
\text { tanggung jawab, cinta damai, } \\
\text { peduli sosial, kerja keras, peduli } \\
\text { lingkungan, rasa ingin tahu, } \\
\text { semangat kebangsaan, } \\
\text { menghargai prestasi, gemar } \\
\text { membaca }\end{array}$ \\
\hline 9. & $\begin{array}{l}\text { Gemar Menuntut Ilmu dan } \\
\text { Mengamalkannya }\end{array}$ & $\begin{array}{l}\text { Religious, disiplin, kerja keras, } \\
\text { tanggung jawab, peduli } \\
\text { lingkungan, gemar membaca, }\end{array}$ \\
\hline
\end{tabular}




\section{Irfani}

ISSN 1907-0969 E ISSN 2442-8272

Volume 16 Nomor 1 Juni 2020

Halaman 82-95

http://journal.iaingorontalo.ac.id/index.php/ir

\begin{tabular}{|c|c|c|}
\hline & & $\begin{array}{l}\text { peduli sosial, semangat } \\
\text { kebangsaan, menghargai prestasi, } \\
\text { rasa ingin tahu, mandiri, kreatif, } \\
\text { cinta tanah air, cinta damai, } \\
\text { gemar membaca, demokratis, } \\
\text { bersahabat, toleransi. }\end{array}$ \\
\hline 10. & $\begin{array}{l}\text { Membiasakan Hidup } \\
\text { Berlandaskan Hukum Islam }\end{array}$ & $\begin{array}{l}\text { Religious, tanggung jawab, } \\
\text { disiplin }\end{array}$ \\
\hline 11. & $\begin{array}{ll}\text { Menyempurnakan } & \text { Agama } \\
\text { Melalui Haji dan Umrah } & \end{array}$ & $\begin{array}{l}\text { religious, tanggung jawab dan } \\
\text { peduli sosial. }\end{array}$ \\
\hline 12. & $\begin{array}{l}\text { Menumbuhkan Solidaritas Sosial } \\
\text { Melalui Zakat }\end{array}$ & $\begin{array}{l}\text { religious, peduli social, dan } \\
\text { tanggung jawab. }\end{array}$ \\
\hline 13. & $\begin{array}{l}\text { Meningkatkan Kesejahteraan } \\
\text { Umat Melalui Wakaf }\end{array}$ & $\begin{array}{l}\text { religious, kepedulian social dan } \\
\text { tanggung jawab. }\end{array}$ \\
\hline 14. & $\begin{array}{l}\text { Meneladani Dakwah Rasulullah } \\
\text { saw. Periode Mekkah }\end{array}$ & $\begin{array}{l}\text { toleransi, demokrasi, bersahabat/ } \\
\text { komunikatif, cinta damai, kerja } \\
\text { keras, kepedulian social, } \\
\text { semangat kebangsaan. }\end{array}$ \\
\hline 15. & $\begin{array}{l}\text { Meneladani Dakwa Rasulullah } \\
\text { saw. Periode Madinah }\end{array}$ & $\begin{array}{l}\text { religious, toleransi, demokrasi, } \\
\text { bersahabat komunikatif, cinta } \\
\text { damai, kerja keras, }\end{array}$ \\
\hline
\end{tabular}

Pada Buku PAI dan Budi Pekerti untuk SMK kelas X ini sudah termuat nilai-nilai pendidikan karakter pada setiap materi atau pembahasan, akan tetapi guru sebagai pendidik perlu mengembangkan kembali muatan-muatan nilai pendidikan karakter dalam pada proses kegiatan belajar mengajar agar bisa membentuk karakter dari peserta didik dan nilai-nilai pendidikan karakter dapat terintegrasi dengan baik.

Strategi Pengintegrasian Pendidikan Karakter Pada Buku Mata Pelajaran Pendidikan Agama Islam Kelas X SMK

Di dalam buku Mata Pelajaran Pendidikan Agama Islam dan Budi pekerti Kelas X SMK terdapat beberapa intruksi yang tidak jauh berbeda dengan strategi yang digunakan dalam menyampaikan materi agar dapat disampaikan kepada peserta didik dengan tepat dan benar.Instruksi itu seperti Tadarus dan Terjemah Al-Quran "Bacalah Q.S. Al-Anfal: 72 secara 


\section{Irfani}

ISSN 1907-0969 E ISSN 2442-8272

Volume 16 Nomor 1 Juni 2020

Halaman 82-95

http://journal.iaingorontalo.ac.id/index.php/ir

tartil dan baca pula Terjemahnya selama lima menit. Perhatikan makhraj dan tajwidnya", Tafakur yang berisi ajakan berfikir yang berhubungan dengan materi pembelajaran. Yang dengan demikian, peserta didik dapat mengambil pelajaran atau hikmah sekaligus sebagai bahan renungan bagi peserta didik, aktivitas yang berisi kegiatan yang dilakukan peserta didik, contohnya "ada Sembilan kegiatan yang perlu anda lakukan untuk mempraktikkan mujahadah 'an-nafs/ kontrol diri yaitu: 1) menunaikan shalat lima waktu; 2) menunaikan shalat berjamaah sesering mungkin; 3) berbuat baik kepada orangtua, baik yang masih hidup atau yang sudah meninggal; dll." Studi kasus, dan kisah teladan.

Intruksi tersebut membawa guru atau pembaca untuk menggunakan strategi yang dilaksanakan dalam proses pengaplikasian pembelajaran melalui buku ajar tersebut. Yaitu pada kegiatan aktivitas.Aktivitas berisi kegiatan yang dilakukan peserta didik berupa kegiatan aplikatif dan bernilai yang berhubungan dengan materi pembelajaran.Kegiatan aktivitas ini untuk membiasakan peserta didik mempraktikkan kegiatan-kegiatan didalam aktivitas tadi pada kehidupan sehari-hari.

Di dalam buku ajar ini juga untuk menambah wawasan peserta didik, di dalam buku ini terdapat Cahaya Hadits yang diharapkan peserta didik dapat meneladani perilaku Nabi Muhammad saw., dalam kehidupan sehari-harinya, studi kasus yang berisis tentang kegiatan penelaahan suatu kasus dalam kehidupan sehari-hari yang erat kaitannya dengan materi pembelajaran, Kisah Teladan, tokoh Islam disini berisi tokoh-tokoh yang berpengaruh didunia dan diharapkan peseta didik mengenal serta memperkaya pengetahuan tentang tokoh-tokoh Islam yang berpengaruh. DanThe Miracle of Islamyang berisi informasi keindahan dan keajaiban agama Islam. Kemudian terdapat tugas-tugas yang berkaitan dengan penilaian sikap, evaluasi pengetahuan dan penilaian keterampilan yang dapat digunakan sebagai bahan penguatan nilai sikap religious dan dan sosial peserta didik. Pada penilaian sikap peserta didik diberikan pernyataan untuk menilai sikapnya dengan memberikan tanda centang beserta alasannya pada kolom yang terdapat pada buku ajar Pendidikan Agama Islam dan Budi Pekerti untuk SMK kelas $\mathrm{X}$.

Tabel. 4 Penilaian Sikap Peserta Didik

\begin{tabular}{|c|c|c|c|c|c|}
\hline \multirow{2}{*}{ No. } & \multirow{2}{*}{ Pernyataan } & \multicolumn{3}{|c|}{ Jawaban } & \multirow{2}{*}{ Alasan } \\
\hline & & $\mathrm{S}$ & TS & $\mathrm{Rg}$ & \\
\hline 1. & $\begin{array}{l}\text { Ketika ada pembangunan } \\
\text { rumah ibadah untuk penganut } \\
\text { agama selain Islam, saya } \\
\text { terpanggil karena merasa } \\
\text { sebagai bentuk Ukhuwwah } \\
\text { basyariyah }\end{array}$ & & & & \\
\hline
\end{tabular}




\section{Irfani}

ISSN 1907-0969 E ISSN 2442-8272

Volume 16 Nomor 1 Juni 2020

Halaman 82-95

http://journal.iaingorontalo.ac.id/index.php/ir

Kemudian pada tugas kelompok, terdapat pada penilaian keterampilan yaitu "peserta didik dibagi menjadi beberapa kelompok, dan diperintahkan untuk membuat time line tentang ukhuwwah yang dicontohkan Rasulullah." Selain mengerjakan tugas yang diberikan, peserta didik juga mempraktekkan bagaimana bekerja dengan orang lain untuk mencapai tujuan dan hasil bersama.

Kisah-kisah teladan didalam buku ini sangat cocok dengan jiwa peserta didik yang memerlukan contoh teladan dan panutan yang dapat dijadikan model didalam kehidupannya karena begitu banyak tantangan dan problema yang akan mereka hadapi, dan bisa dijadikan sebagai pendidikan berbentuk kisah-kisah teladan. Kisah-kisah teladan banyak disukai oleh semua kalangan karena lebih menarik minat peserta didik dan kisah-kisah teladan mengedepankan olah hati dan rasa.

Di dalam buku mata pelajaran ini sudah memberikan petunjuk-petunjuk pemakaian yang melibatkan guru, peserta didik dan orangtua.Dalam proses pembelajaran, pendidikan karakter dimulai pada tahap perencanaan, kemudian pelaksanaan, dan akhirnya dievaluasi.

Berikut ini penjelasannya:

a. Perencanaan pembelajaran

Perencanaan adalah proses penyusunan polakegiatan pembelajaran yang akan dilakukan untuk mencapai tujuan. Dalam silabus dan RPP memuat KI, KD, tujuan pembelajaran, strategi dan metode pembelajaran, evaluasi pembelajaran, indicator pencapaian kompetensi, alokasi waktu, materi pembelajaran dan sumber belajar. Dalam perencanaan pembelajaran pendidikan karakter perlu dilakukan perubahan pada tiga komponen silabus dan RPP, yaitu:

1) Penambahan atau modifikasi kegiatan pembelajaransehingga ada kegiatan pembelajaran yang dapat mengembangkan karakter peserta didik.

2) Penambahan atau modifikasi pencapaian sehingga ada indikator yang terkait dengan pencapaian peserta didik dalam hal yang berkaitan dengan karakter.

3) Penambahan atau modifikasi teknik penilaian yang dapat mengembangkan atau mengukur perkembangan karakter peserta didik.

RPP memiliki peran penting dalam mengintegrasikan nilai-nilai pendidikan karakter ke dalam proses pembelajaran disekolah. Karena RPP merupakan gambaran tentang bagaimana pembelajaran akan dilakukan.

b. Pelaksanaan pembelajaran karakter

Pelaksanaan pendidikan karakter tentunya tidakterlepas dari perencanaan yang telah dilakukan sebelumnya.Jadi pelaksanaan pembelajaran merupakan implementasi dari RPP.Pelaksanaan pembelajaran meliputi pendahuluan, kegiatan inti, dan kegiatan penutup.Pendidikan haruslah masuk di dalam setiap kegiatan tersebut.Praktik penanaman 


\section{Irfani}

ISSN 1907-0969 E ISSN 2442-8272

Volume 16 Nomor 1 Juni 2020

Halaman 82-95

http://journal.iaingorontalo.ac.id/index.php/ir

pendidikan karakter harus dilakukann dengan tepat. Pusat Kurikulum Kementerian Pendidikan Nasional dalam kaitannya dengan pengembangan budaya sekolah yang dilaksanakan dalam kaitan pengembangan diri, menyarankan empat hal yang meliputi:

1) Kegiatan rutin

Kegiatan rutin merupakan kegiatan yang dilaksanakanpeserta didik secara terus-menerus dan konsisten setiap saat.

2) Kegiatan spontan

Bersifat spontan saat itu juga, pada waktu terjadikeadaan tertentu, misalnya mengumpulkan sumbanganbagi korban bencana alam.

3) Keteladanan

Timbulnya sikap dan perilaku peserta didikkarena meniru perilaku dan sikap guru dan tenaga kependidikan di sekolah, bahkan seluruh warga sekolah yang dewasa lainnya sebagai model.

4) Pengkondisian

Penciptaan kondisi yang mendukungketerlaksanaan pendidikan karakter. Menurut

Masnur Muslich menyatakan beberapa metode yang dapat digunakan dalam mengimplementasikan pendidikan karakter, di antaranya:
a) Keteladanan
b) Kegiatan spontan
c) Teguran
d) Pengondisian lingkungan
e) Kegiatan rutin. ${ }^{12}$

Penanaman pendidikan karakter jangan hanya dilakukan di dalam ruangan kelas, akan tetapi dilakukan disetiap kegiatan dan dilingkungan sekolah pengajar ataupun pendidik harus mampu memberikan suri teladan atau dapat mengarahkan peserta didik untuk bertindak sesuai dengan nilai-nilai karakter yang baik. Karakter tidak hanya sebatas pengetahuan.Harus dibarengi dengan praktek ataupun latihan dalam mengintegrasikan ke dalam kehidupan sehari-hari dan dilakukan secara terus-menerus dan konsisten.

\section{KESIMPULAN}

Melihat dari segi materi yang tercantum di atas, muatan pendidikan karakter sudah termuat baik secara tekstual ataupun kontekstual. Berdasarkan 18 nilai karakter menurut Kementerian Pendidikan Nasional, nilai-nilai pendidikan karakter yang terkandung atau termuat didalam buku ajar Pendidikan Agama Islam dan Budi Pekerti SMK kelas X yang ditemukan

\footnotetext{
${ }^{12}$ Masnur Muslich, Pendidikan Karakter Menjawab Tantangan Krisis Multidimsional, (Jakarta: Bumi Aksara, 2011), Hal. 175
} 


\section{Irfani}

ISSN 1907-0969 E ISSN 2442-8272

Volume 16 Nomor 1 Juni 2020

Halaman 82-95

http://journal.iaingorontalo.ac.id/index.php/ir

penulis yaitu Religius, kerja keras, semangat kebangsaan, bersahabat/komunikatif, cinta damai, peduli lingkungan, peduli social, tanggung jawab, demokrasi, disiplin, jujur, rasa ingin tahu, menghargai prestasi, gemar membaca, kreatif, toleransi.

\section{SARAN}

1. Untuk kesesuaian nilai-nilai pendidikan karakter yang tercantum pada Buku Pendidikan Agama Islam dan Budi Pekerti untuk SMK kelas X ini perlu disempurnakan dengan pengembangan karakter pada proses pembelajaran atau kegiatan pembelajaran.

2. perlunya dikembangkan dengan sebaik mungkin nilai-nilai pendidikan karakter pada buku ajar agar karakter peserta didik dapat terbentuk dengan baik karena pembentukkan memerlukan perencanaan, metode dan strategi yang tepat.

3. Penanaman pendidikan karakter jangan hanya dilakukan di dalam ruangan kelas, akan tetapi dilakukan disetiap kegiatan dan dilingkungan sekolah.

\section{DAFTAR PUSTAKA}

Abdul Majid, Perencaan Pembelajaran Mengembangkan Standar Kompetensi Guru, Bandung: PT Remaja Rosdakarya, 2006.

Alwisol. Psikologi Kepribadian. Malang: UMM. 2006.

Arikunto, S. Prosedur Penelitian Suatu pendekatan Praktik. Jakarta; Rineka Cipta. 2010.

Masnur Muslich, Pendidikan Karakter Menjawab Tantangan Krisis Multidimsional, Jakarta: Bumi Aksara, 2011.

Nasir, Haedar, Pendidikan Karakter Berbasis Agama dan Budaya. Yogyakarta: Multi Press, 2013.

Pendidikan Agama Islam dan Budi Pekerti untuk SMK Kelas X Kurikulum 2013,Edisi Revisi 2016, Jakarta: Penerbit Erlangga, 2016.

Putri Puspitaningsih, Sumber-sumber Pendidikan Karakter, STKIP PGRI Pacitan. 2014

Risnawati, Implementasi Niai-Nilai Karakter pada Mata Pelajaran Pendidikan Agama Islam (PAI) Tingkat SLTA, Pontianak: IAIN Pontianak Press, 2014.

Sari, Dewi Purnama. 2017. "Pendidikan Karakter Berbasis Al-Quran". Islamic Counseling, 1 (1): 1-24. P-ISSN 2580-3638, E-ISSN 2580-3646.

Undang-undang Nomor 20 Tahun 2003 pasal 3 tentang Sistem Pendidikan.

Wynne, E. A. 1991. "Character And Academics In The Elementary School". Dalam Benninga J.S. (Penyunting). Moral, Character,And Civic Education In The ElementarySchool. New York: Teachers College, Columbia University.

Zubaedi, Desain Pendidikan Karakter: Konsepsi dan Aplikasinya dalam Lembaga Pendidikan. Jakarta: Kencana. 2011.

Sanjaya, Wina, Perencanaan dan Sistem Desain Pembelajaran, Jakarta: Kencana. 2010 